\title{
Investing in education in Europe: Evidence from a new survey of public opinion
}

Journal of European Social Policy 2018, Vol. 28(I) 34-54 (C) The Author(s) 2017 Reprints and permissions: sagepub.co.uk/journalsPermissions.nav DOI: $10.1177 / 0958928717700562$ journals.sagepub.com/home/esp @SAGE

\author{
Marius R. Busemeyer, Julian L. Garritzmann \\ and Erik Neimanns \\ University of Konstanz, Germany
}

\section{Roula Nezi}

GESIS - Leibniz Institute for the Social Sciences, Germany

\begin{abstract}
Public opinion research has found that increasing the investment in education is generally very popular among citizens in Western Europe. However, this evidence from publicly available opinion surveys may be misleading, because these surveys do not force respondents to prioritize between different parts of the education system or between education and other social policies, nor do they provide information about citizens' willingness to pay for additional investment in education. To address these deficiencies, we conducted an original, representative survey of public opinion on education and related policies in eight European countries. Our analysis confirms that citizens express high levels of support for education even when they are forced to choose between education and other areas of social spending. But not all educational sectors enjoy equally high levels of support: increasing spending on general schooling and vocational education is more popular than increasing spending on higher education and early childhood education. Furthermore, we find that citizens are, in fact, willing to pay additional taxes in order to finance investment in education, at least in some countries and for some sectors of the education system.
\end{abstract}

\section{Keywords}

Attitudes towards public spending, education, financing of social spending, INVEDUC survey, welfare state

\section{Introduction}

Increasing public investment in education remains high on the political agenda of policymakers in Europe and beyond. For example, the 'Europe 2020' strategy of the European Union (EU) and the associated

\author{
Corresponding author: \\ Marius R. Busemeyer, University of Konstanz, PO Box D 79, \\ D-78457 Konstanz, Germany; \\ Email: Marius.Busemeyer@uni-konstanz.de
}


'Education and Training 2020' programme have set ambitious goals, such as reducing dropouts from school to less than 10 percent of students and increasing the share of young adults with a tertiary education degree to more than 40 percent. ${ }^{1}$ In many European countries, meeting these ambitious targets will require additional public (and potentially private) investment in education. At the same time, investing in education is believed to play a key role in dealing with the recent trend of increasing socioeconomic inequality associated with the rise of the globalized service-based knowledge economy (Busemeyer, 2015; Goldin and Katz, 2008; Huber and Stephens, 2014).

The political conditions for increasing the levels of education spending are not always propitious, however. On the one hand, many European countries are still suffering the aftershocks of the global economic and fiscal crisis, resulting in tight budget constraints. Discretionary types of spending such as social investment have been found to be more susceptible to retrenchment pressures during times of fiscal austerity compared to social entitlement programmes (Breunig and Busemeyer, 2012; Streeck and Mertens, 2011). Expanding spending in times of austerity therefore seems unlikely. On the other hand, policy proposals to expand educational opportunities can be considered the 'archetypical crowd-pleaser' (Ansell, 2010: 136). In existing surveys of public opinion, proposals to increase public spending on education are supported by huge majorities in most Organization for Economic Cooperation and Development (OECD) countries (Ansell, 2010: Chapter 4; Busemeyer, 2015: Chapter 5; Garritzmann, 2015). Not surprisingly, political parties do not disagree on whether to expand education but differ mostly with regard to the emphasis they place on this issue relative to others (Busemeyer et al., 2013).

Despite this high level of popular demand, in many countries, the actual spending levels have remained constant or even declined. In Germany, for example, public education spending has barely increased from $4.9 \%$ of gross domestic product (GDP) in 2000 to $5.1 \%$ in 2011 , despite a strong increase in student numbers. In France, spending actually fell from $6.4 \%$ to $6.1 \%$ during the same time period (OECD, 2014: 231). So far, most of the explanations given for this apparent mismatch between public demands and policy output have focused on the latter. The reason that public spending on education is more constrained than other types of social spending could be because - as mentioned above - the political economy of budgetary decisions protects social entitlement programmes to the detriment of investment-oriented discretionary spending. Furthermore, there is mounting evidence that public spending, in general, is more constrained by the forces of economic globalization in the contemporary period compared to previous periods (Busemeyer, 2009; Jahn, 2006).

In this article, we want to focus on the input side of the political process, namely public opinion on education policy. Given the numerous shortcomings in existing surveys of public opinion, which we explain in detail below, the general understanding of the dynamic of public opinion on education is very limited. In particular, it is largely unknown whether citizens - when forced to make a choice - would indeed privilege education over other kinds of social spending. It could well be the case that citizens would rather tolerate underinvestment in education than cutbacks to popular social transfer programmes. Furthermore, very little is known about on which type of education citizens would like public investment to be concentrated. Providing a comprehensive answer to these questions is crucial in order to better understand why investing in education seems to be very popular on the level of political rhetoric but not necessarily on the level of policy output.

To provide answers, this article presents evidence from an original survey of public opinion on education and other social policies, which was conducted in 2014 in eight Western European countries. We introduce and describe this survey in detail below. Furthermore, we concentrate on presenting largely descriptive statistics, as well as some interpretative and explorative analyses of the variation in public opinion on education policy across countries. More sophisticated statistical analyses of the determinants of these attitudes are undertaken elsewhere (for example in Busemeyer and Garritzmann, 2017). Thus, the contribution of this article is mainly empirical, and it should be considered a first step towards the development of a more fine-grained and nuanced understanding of the micro-level and cross-country dynamics of public attitudes towards education policy. 
Nevertheless, the exploratory analysis in this article yields some important findings. First, the evidence confirms that education is very popular among European citizens, even when they are forced to choose between education and other social policies. We also find, however, that public opinion is divided on the question of which kind of education public expenditure should be concentrated on. In contrast to common assumptions in the literature, we find that citizens, on average, prefer to increase public spending on general (primary and lower secondary) schools and on vocational education rather than on early childhood and higher education, even though the latter two are usually central in political debates about the future of education and feature prominently in the current 'social investment' literature (Bonoli, 2013; Esping-Andersen, 2002; Hemerijck, 2013). Furthermore, our survey also indicates that citizens' demands are not just 'cheap talk', since we find that the majority would accept non-trivial tax hikes in exchange for additional public investment in education.

\section{Background: the current state of research into public opinion on education}

The comparative analysis of public attitudes towards the welfare state (and other public policy) has become a major field of research in recent years (see Svallfors, 2012, for a recent overview) as a consequence of the establishment of cross-national survey programmes, such as the International Social Survey Programme (ISSP), the European Social Survey (ESS), the Eurobarometer and the World/ European Value Survey (WVS/EVS). The first generation of comparative studies was often confined to the comparison of a limited number of individual country cases (for example Bean and Papadakis, 1998; Hasenfeld and Rafferty, 1989; Svallfors, 1997) and more concerned with identifying individuallevel determinants of welfare-state attitudes, such as income, education, age, gender and partisan ideology. With the expanding number of countries covered in the cross-national survey programmes, the focus of analysis turned from individual-level factors towards exploring the feedback effects of macro-level welfare-state institutions on the microlevel of preferences and attitudes (see, for example, Andre $ß$ and Heien, 2001; Blekesaune and Quadagno, 2003; Campbell, 2012; Finseraas, 2009; Gingrich and Ansell, 2012; Jaeger, 2006, 2009; Mettler and Soss, 2004; Svallfors, 1997, 2004, 2010, 2012). More recently, scholars have become interested in understanding the linkages between public opinion and actual policy output (Brooks and Manza, 2006, 2007; Rehm, 2012; Rehm et al., 2012; Soroka and Wlezien, 2010). Recent work has also expanded our knowledge about additional determinants of individual-level support for the welfare state by highlighting the impact of factors, such as skill specificity (Iversen and Soskice, 2001), labour market risk (Rehm, 2009), perceptions of deservingness (Van Oorschot, 2006) and religion (De La O and Rodden, 2008; Scheve and Stasavage, 2006). Finally, scholars have begun to analyse the impact of the Great Recession on social-policy preferences (Margalit, 2013).

The bulk of existing scholarship in comparative welfare-state research is concerned with studying public attitudes towards more traditional social policies, such as healthcare, unemployment insurance and pensions, as well as public support for government-induced redistribution more broadly defined. Scholars of education systems and education policy, in turn, do not study individual preferences on education policy for the most part, being more concerned with the analysis of educational choices, attainment and educational inequality (see, for example, Breen et al., 2009; Shavit and Blossfeld, 1993). Consequently, there is very little research about public opinion on education policy, which is most probably related to two factors: first, the study of education policy has not featured prominently in comparative public policy and welfare-state research (Busemeyer, 2015; Busemeyer and Trampusch, 2011; Iversen and Stephens, 2008; Jakobi et al., 2010), and recent contributions in this field mostly focus on the aggregate level of policy output rather than public opinion. A second reason is the dearth of more finegrained public opinion data on education compared to other social policies (discussed in detail below).

Recently, however, there has been more scholarly interest in exploring public opinion on education 
policy. As in contemporary welfare-state research, existing scholarship about public opinion on education policy is often concerned with the analysis of institutional feedback effects. For example, Ansell (2010) and Busemeyer (2012) argued that the degree of stratification of educational institutions shapes patterns of public support: individuals in the upper income classes are more likely to support public investment in education if access to higher levels of education is limited. Busemeyer and Iversen (2014) added to this perspective by showing that highincome individuals are more likely to support public rather than private provision of education in countries where the public component is already dominant and opportunities to 'opt out' of public schemes are more limited. Garritzmann (2015) complemented these analyses by studying preferences for financial student aid using ISSP data for more than 20 countries over two decades. He showed that respondents' education policy preferences are affected by materialistic self-interest, their ideological positions and by positive feedback effects of the existing education systems. There is also some evidence that generational cleavages between the young and old are more important in the case of education than in other social policies (Busemeyer et al., 2009; Cattaneo and Wolter, 2009) - a finding that earlier studies support for the case of the United States (Button, 1992; Poterba, 1998). Busemeyer et al. (2011) demonstrated for the case of Switzerland that individual educational experiences and partisan ideology have strong effects on public attitudes as well. Using a number of survey experiments, Lergetporer et al. (2016) studied how the provision of information influences public attitudes towards education policy (see also Wößmann et al., 2014).

Building on these studies, the aim of this article is to advance our understanding of the micro-level dynamics of public opinion on education policy. More specifically, we are interested in public opinion about public spending on different sectors of the education system (from pre-primary to higher education), how these preferences relate to spending preferences for other social policies and the extent to which preferences towards education spending correspond with support for higher levels of taxation in that area. The article aims to contribute to the existing literature by offering a more fine-grained comparative analysis of public opinion towards education policy.

Even though scholarly interest on the topic has increased significantly, further progress has been stymied somewhat by a number of shortcomings in existing surveys. One widely used dataset is the ISSP's 'Role of Government' (RoG) module, which contains questions on individual support for the expansion of public spending on a variety of social policies, including education. The advantage of the ISSP survey is that it covers a large number of countries (33 in the latest wave, in 2006), which makes it possible to use multilevel regression analysis to study the moderating impact of socioeconomic contexts and political institutions on the micro-level dynamics. Another advantage of the ISSP data is that it allows for analyses of changes over time, at least for some countries, since there are four waves of the ISSP RoG module available between 1985 and 2006 (a fifth wave will be available soon).

One significant downside of the ISSP survey, however, is that it does not distinguish between different sectors of the education system. Therefore, it does not contain information on individual attitudes for different kinds of education (academic, vocational, general, etc.). Furthermore, although the wording of the specific question includes a brief note that increasing spending could lead to higher taxes, the trade-offs between different kinds of social policies are not modelled in a satisfactory way. Since respondents are not forced to make choices between different policies, the ISSP data blur the distinction between individual support for public spending in general and public spending on education more specifically. Finally, the wording of the question does not acknowledge differences in the status quo in different countries, because it only asks about increases or decreases in spending, not about the desired total amount.

A second potential data source is the ESS. This survey programme also provides data on a large number of European countries, so that it is possible to study how institutional contexts affect attitudes. However, the ESS does not contain any survey questions on individual education policy preferences in the core module, except a very general one on the 'state of 
education'. In one wave (2008-2009), the ESS actually included a specific module on 'welfare state attitudes' (which is analysed in detail in Svallfors, 2012), but tellingly, this module does not include any questions on education. Other widely used datasets, such as the Eurobarometer and the World Values Survey, do not include any specific questions on education policy preferences either or only include weakly framed and very specific questions.

\section{Survey design, methodology and data collection of the INVEDUC survey}

Given these shortcomings, we conducted our own survey of public opinion in eight European countries: the INVEDUC survey (in the context of the project 'Investing in Education in Europe: Attitudes, Politics and Policies'). This survey covers Denmark, France, Germany, Ireland, Italy, Spain, Sweden and the United Kingdom. This selection of cases was motivated by the desire to have two cases for each 'world of welfare capitalism' (Esping-Andersen, 1990) or 'world of human capital formation' (Iversen and Stephens, 2008) in Western Europe. ${ }^{2}$ The United Kingdom and Ireland represent the liberal welfare-state regime, Sweden and Denmark the social-democratic, and Germany and France the conservative. Southern European countries are sometimes considered to form a separate regime type (for example see Bonoli, 1997; West and Nikolai, 2013 for the case of education more specifically), so we also included Spain and Italy in our survey. A necessary limitation of our survey is that we are unable to make claims about the countries we could not include. It remains a task for future research to analyse public opinion towards education policy in Eastern European and non-European countries and to compare the results to ours.

There are four major innovations in our survey in comparison with the often-used ISSP RoG module. First, in comparing preferences for education spending with support for other social policies, we include additional spending categories reflecting the changing character of contemporary welfare states: spending on the poor, on families and on active labour market programmes. This accounts for the increased public and scholarly attention (Bonoli, 2013; Hemerijck, 2013) paid to family policy and active labour market policy (ALMP), as well as the increasing relevance of the phenomenon of the 'working poor'. Second, in addition to asking respondents about their support for education spending in general, we use a more fine-grained scheme that allows us to identify relative preferences for different types of education: preschool education, general (primary and secondary) schooling, vocational education and training (VET) and academic higher education. This is important and interesting, because it is by now well known that the redistributive dynamics (and consequently the politics) differ starkly across educational sectors. Higher education, for example, can have financially progressive or regressive implications depending on the enrolment level (Ansell, 2010; Fernandez and Rogerson, 1995) and the characteristics of the respective funding system (Garritzmann, 2016). Third, in order to provide a better understanding of how prominently education spending features in public opinion vis-à-vis other spending areas, respondents are also forced to identify only one particular spending area which they believe should be prioritized in order to avoid 'cheap talk' in their expression of spending preferences. This is done both in the comparison of education with other policy fields and in the comparison of preferences for different types of education. Finally, our survey asks for the respondents' willingness to accept additional taxes to finance investment increases in different education sectors and the amount they would each personally be willing to contribute. Taken together, these modifications address major shortcomings in international survey research. ${ }^{3}$

The fieldwork for the INVEDUC survey was conducted by a professional survey company specializing in cross-national surveys of public opinion. The chosen surveying technique was computerassisted telephone interviewing (CATI) - a method that has become dominant since the mid-1980s because it was deemed capable of achieving the same level of quality as face-to-face interviews at lower costs (Krosnick, 1999). The universe of our survey was adults (aged 18 and above) selected via random probability sampling. This sampling method ensures that every individual from a given population, in our case from every country in the survey and from every social level within each country, has 
an equal likelihood of being interviewed (Pennings et al., 2006). The sampling method is crucial in order to increase the degree of representativeness. An increasing percentage of the population use only mobile phones, so we included both landlines and 'mobile-only' citizens in our sample (See Link et al., 2007). Since mobile-only citizens are usually not included in telephone registers, we employed the common method of random digit dialling (RDD), in which mobile phone numbers are picked at random extrapolating from existing mobile numbers. The only exception is Sweden, since in this country, the existing address register covers about 90 percent of the population (for details, see the technical report to the INVEDUC survey: Gensicke et al., 2014).

The fieldwork for the survey was conducted between mid-April and the end of May 2014. During this period, a total of 8905 valid interviews were conducted. The number of interviews in each country (see Table A3 in the online appendix) varied between 1000 and 1500, reflecting differences in the size and socioeconomic composition of the respective populations. The average response rate was $27 \%$ (with a low of $20 \%$ in Ireland and a high of $36 \%$ in Denmark). ${ }^{4}$ In general, these response rates are satisfactory and typical for these kinds of surveys, especially considering that survey research has been suffering from a general decline in response rates (Steeh, 1981; but see the critical discussion in Stoop et al., 2010) since the early 1980s. Furthermore, response rates are not necessarily related to biased samples. Investing significantly in the sampling process reduces the danger of bias. Furthermore, applying carefully constructed sampling weights can effectively address the remaining differences between responding and non-responding populations (Groves, 2006).

Both population and design weights are included in our descriptive analysis below. Design weights correct for different selection probabilities: by accounting for non-response bias (Groves, 2006), they make the sample more representative and closer to a 'true' sample of the population aged 18+. Population weights are used when more than one country is included in the analysis. These types of weights control for the differences in the socioeconomic composition of populations between countries. For example, as in most other social surveys, most countries included in our survey have similar sample sizes, even though their real population differs. The population weights control for these differences and make the necessary adjustments to ensure that each country is represented in the overall pool in proportion to its population size (for details, see the discussion in the background report on response rates and the weights: Gensicke et al., 2014: 17-23). As another robustness check, Table A1 in the online appendix compares the distribution of some key demographic variables in the INVEDUC survey with data from the ESS waves of 2012 and 2014. This comparison shows that in general, there is little discrepancy between our data and the ESS data (which is usually regarded as the gold standard in survey research). This adds to our confidence about the representative nature of our sample.

Another challenge of cross-national surveys such as ours is that the survey is conducted in different countries with different languages. Interviews should ideally be conducted in the national language by native speakers of that language, since the expectation is that the quality of the collected data increases when the national language is used during the interview. We implemented this standard in the present survey, working with a professional survey company that has offices and/or representatives in each of the countries included in the analysis.

We designed the questionnaire in English and then translated into each national language. Our goal for each national language was to generate a translation as close as possible to the original document while making sure that all questions had the same meaning and were understood across all languages. As with all other high-quality cross-national surveys in Europe, the methodology used for the translation process included five distinct steps: translatability check, translation, linguistic quality control (LQC), pretest and final quality control (Harkness et al., 2010). The master questionnaire was first submitted to a thorough translatability assessment by our linguistic partner, cApStAn, in which professionals specialized in each of the languages produced a draft translation of all items for each language. These translations helped to identify the issues the professional translators would face (for example cultural differences, unnecessary complexities, idiosyncrasies). The questionnaire was then translated by professional translators 
using computer-aided translation (CAT) tools, which help to provide consistency and completeness during the translation process. In the subsequent phase of LQC, the 'verifiers', as they are usually called, made sure that the questionnaires were free from remaining grammar, punctuation and syntax errors. The final outcome of this stage was then evaluated by a senior linguistic expert in each respective language. A similar approach is used by the ESS. Detailed information on the various steps taken can be found in the background report (Gensicke et al., 2014: 5-10).

Our final step before the actual fieldwork was to test our questionnaire in a pretest survey. During the pretest period, researchers are able to identify questions that respondents have difficulty in understanding and other issues related to the design of the questionnaire. We conducted about 25 pretest interviews in each of the eight included countries. Following the pretest, a debriefing session was organized that provided an opportunity to discuss the interviewers' experiences. A further objective of the pretest survey was to train the interviewers and identify potential problems in the implementation. The background report (Gensicke et al., 2014) discusses these and related issues in much more detail.

\section{Empirical findings}

The following section provides empirical findings from our INVEDUC survey. First, we present an overview on public opinion towards education spending relative to other social policies. Second, we focus on preferences regarding the distribution of spending across different educational sectors (early childhood education, general schooling, vocational education and academic higher education). Within these two broader topics, we first discuss the respondents' policy preferences on spending when they were not forced to prioritize between different policies. In the second step, we look at attitudes when respondents were forced to name only one policy area (education against other social policies in the first case, different sectors of the education system in the second), in which spending should be increased. Finally, we look at respondents' willingness to pay for different kinds of education in the form of higher taxes.

\section{Public opinion on the importance of education spending relative to other social policies}

The first question we used to measure public support for education spending relative to other social policies replicates the widely used question in the ISSP RoG module. The exact wording is

In the following, I will name several areas of government activity. Please tell me whether you would like to see more or less government spending in each area. Keep in mind that 'more' or 'much more' might require a tax increase.

One crucial difference from (and extension of) the ISSP version, however, is that we included additional policy fields that reflect new policy-making priorities in European welfare states. The policy fields mentioned in the survey are healthcare, unemployment benefits, old-age pensions, social assistance to the poor, financial support for families, education, labour market and public employment programmes, defence and environmental protection (the latter two are included to enable the comparison of support for social policies with support for non-welfare policies). The order of the respective answer categories was randomized for each respondent so that the sequencing would not affect answer patterns. Respondents' preferences for government spending are captured on a five-point scale, where higher values indicate a preference for more spending (much less spending $=1$, less $=2$, the same $=3$, more $=4$ and much more $=5$ ).

The first striking observation is that across all policy fields, the highest level of support is for increased spending on education. When aggregated across countries, a large majority of European citizens (almost 80 percent) prefer higher levels of spending on education. From this perspective, and as has been shown in previous studies (Ansell, 2010; Busemeyer et al., 2013), education can indeed be regarded as a valence issue (Green, 2007). Parties and voters, in general, tend to agree on the need for more spending and differ mainly in the emphasis they place on this topic (vis-à-vis other government activities).

Above and beyond education, Figure 1 displays the high levels of support for increased spending on 


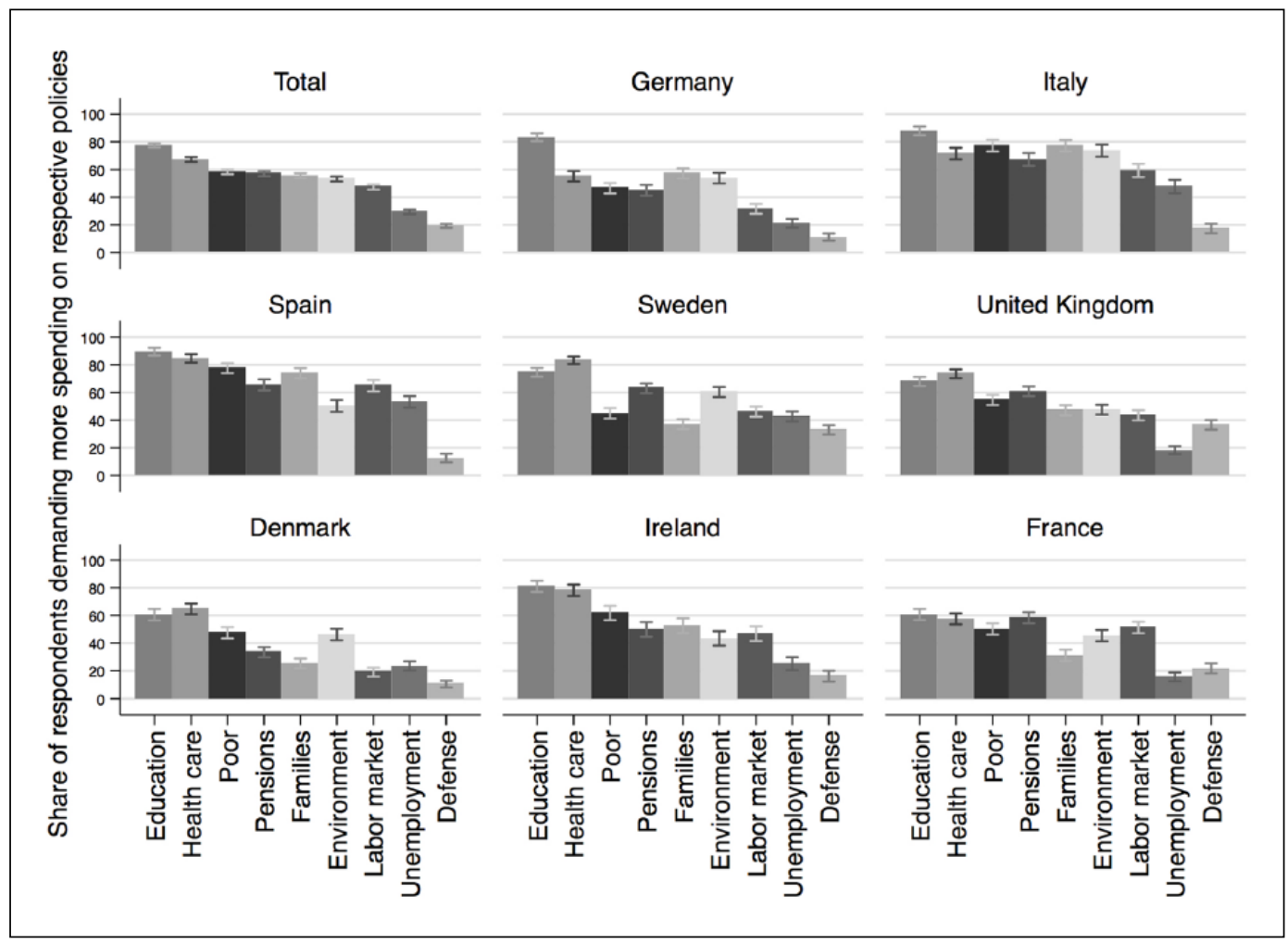

Figure I. Respondents' preferences for different kinds of public expenditure across countries.

healthcare $(67 \%$ of respondents demand higher spending, averaged across all countries), pensions $(58 \%)$ and families (56\%) but markedly less support for increased spending on unemployment benefits $(30 \%)$ and defence $(20 \%)$. ALMP is located in between these extremes, with $48 \%$ of the respondents in favour of more spending. This is generally in line with the literature on 'deservingness' (Van Oorschot, 2006), which argues that the support for spending on welfare-state beneficiaries considered to be 'deserving' should be higher than the support for spending on the 'undeserving' (that is, the sick and disabled as opposed to the unemployed). Our data also, however, show that there is considerable support for spending on social assistance to the poor $(59 \%)$. A final interesting observation is that spending on welfare-state policies is, in general, much more popular than spending on non-welfare state policies: $54 \%$ of the respondents favour spending increases for environmental protection, and only
$20 \%$ favour more spending on defence, while the average value of support for increased spending in the remaining seven categories is $56 \%$. All of these differences are statistically significant against one another (the narrow confidence bands in the figure already indicate this $-t$-test and proportion tests are available on request).

Figure 1 depicts the variation in support for different types of public spending across all countries (using survey weights as discussed above). The bars present the sum of the shares of respondents demanding 'more' or 'much more' spending in the respective categories. All in all, there is a high degree of consistency in the relative importance of spending categories across countries, but there are also some significant differences. What is most important is that the country-by-country analysis confirms that across Europe, education is at the top of the public's agenda. In all countries, with the exception of Denmark, Sweden and the United Kingdom, public 
support for increased spending on education is higher than that for all other policy areas. This pattern is the most pronounced in Germany and could be cautiously interpreted as an indication of 'negative feedback effects' in the sense of Soroka and Wlezien (2010): citizens in countries with aboveaverage levels of spending (Sweden, Denmark) or with recent strong increases in spending (the United Kingdom) are less keen on further expanding spending, whereas the situation is the reverse in countries with below-average spending such as Germany.

Figure 1 shows interesting findings for the other social-policy areas as well. For instance, support for additional financial support for families is lowest in countries with family policies strongly supporting dual-earner families. This includes the Scandinavian countries of Sweden and Denmark but to a lesser extent France. At the other end of the scale, more financial support for families is highest in the familialistic Southern European welfare-state regimes (Spain and Italy) followed by the conservative German welfare state and Catholic Ireland. Again, this is in line with the notion of 'negative feedback'.

With regard to preferences for labour marketrelated spending, preferences partly reflect the country's current economic situation, but there are also some more nuanced differences. Preferences for additional spending on unemployment benefits, the poor and ALMP are highest in Italy and Spain, most probably because the negative consequences of the economic and fiscal crisis are much more visible in these countries compared to Northern Europe. While citizens in the Scandinavian countries are likely to support spending for the poor, Swedish respondents are more in favour of spending increases on unemployment benefits. Furthermore, citizens in the liberal welfare state of the United Kingdom and in France are least supportive of spending on unemployment benefits; the French prefer additional spending on ALMP instead. In Ireland, however, citizens express support for additional spending for the poor rather than for unemployment benefits. The low support for additional spending on unemployment in the United Kingdom and Ireland - despite the fact that these countries already spend below average in these policy fields - indicates that above and beyond negative feedback, different traditions of welfare-state policy also play a role here. A similar observation can be made in the case of healthcare, where support for additional spending is highest in countries with national healthcare systems (especially the United Kingdom, Denmark and Sweden). Taken together, these figures suggest that both economic context and different welfare-state traditions are likely to shape public preferences in the different spending categories.

As discussed above, the major shortcoming of the question frame used so far is that it is 'unconditional', that is, respondents are asked about 'benefits' without simultaneously being reminded of potential 'costs' of increased public spending. We know, however, that support in these unconditional question frames is significantly higher than when respondents are reminded about potential costs (Citrin, 1979; Welch, 1985). To avoid this problem and to investigate how important education expenditure is for respondents vis-à-vis other public expenditures, we next analyse answers towards the question about spending priorities. We asked respondents,

If the government could increase spending for only one area of its activity, which one of the following should it be in your opinion?

The list of policy fields from which respondents could choose is the same as in the previous question (and again the ordering of the answer categories was randomized for each interview). The findings reveal that in the pooled sample, education is again mentioned the most $(29 \%)$, followed by healthcare $(22 \%)$, and ALMPs (15\%). These averages, however, cover a high degree of variation across countries (Figure 2): education and healthcare feature prominently everywhere, and this advantage over other social-policy areas becomes more pronounced when moving from the unconstrained framing to the constrained one. In the majority of countries (Sweden, Spain, the United Kingdom, Denmark and Ireland), a relative majority of respondents support additional spending on healthcare if forced to make a choice. This finding implies that the results for the pooled sample are driven by Germany and Italy (which receive a higher weight in the calculation of the overall average because of their larger populations). In Germany and Italy, education is the area that 


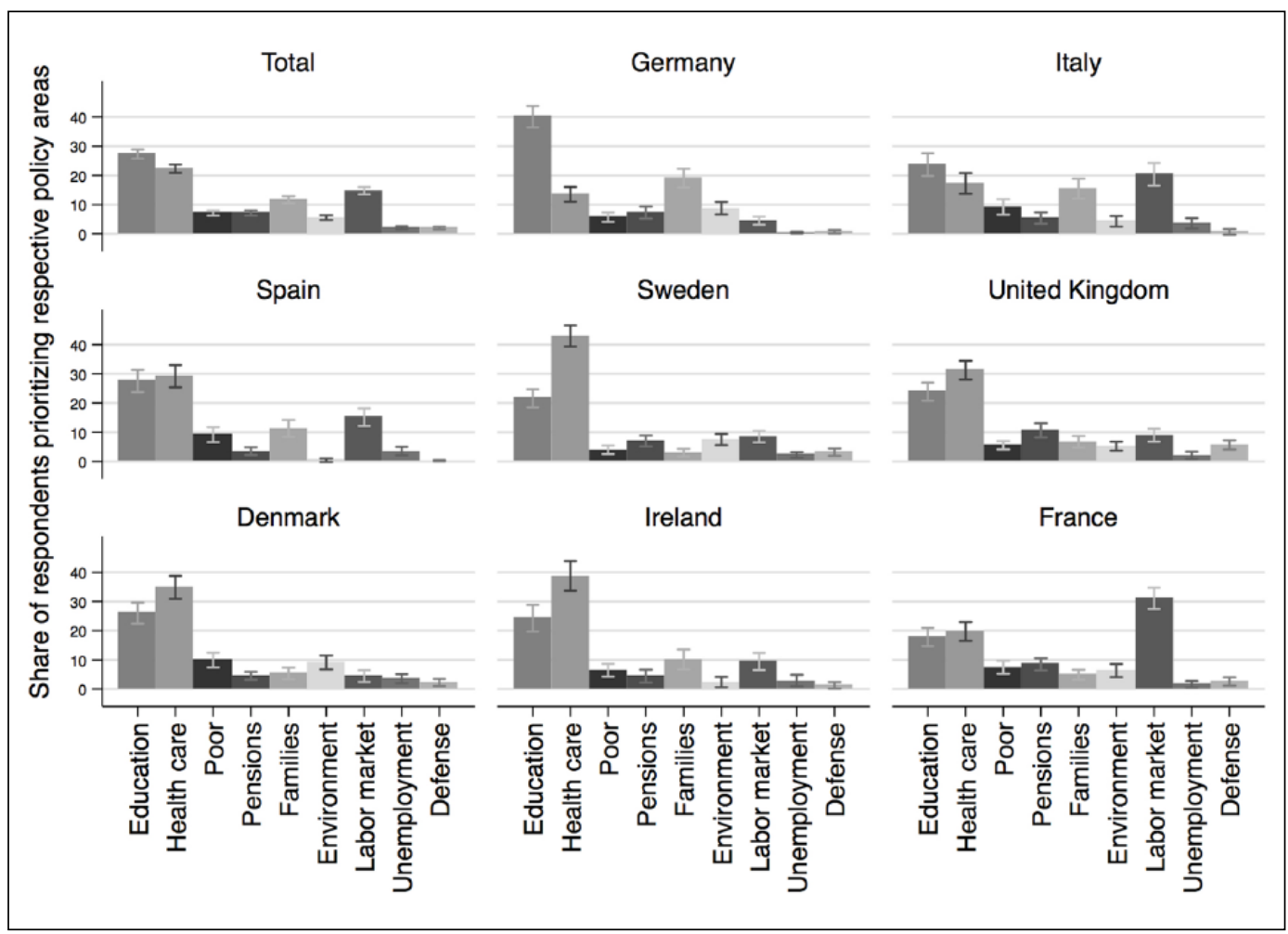

Figure 2. Respondents' preferences for different kinds of public expenditure, when forced to choose one and only one spending area.

receives the highest level of support, whereas French respondents put the highest priority on spending increases for labour market and public employment programmes. This spending area also features prominently in Italy and Spain, a result that is obviously related to the economic situation in these countries. ${ }^{5}$ There is also important variation with regard to financial support for families. Nearly a fifth of German respondents (19\%) state this item as their priority for spending increases but hardly anyone sees this as a priority in Sweden (3\%), Denmark (5\%) or France $(5 \%)$.

These findings can be regarded as an important complement to the previous ones. For one, forcing respondents to choose between different policy areas shows that education features very prominently on the public's agenda. Nonetheless, healthcare is regarded as even more pressing in a majority of countries. Furthermore, support for healthcare is again very strong in countries with national healthcare systems, but it remains unclear whether citizens' support for additional spending is high in these countries because the existing institutional arrangements are so popular or because citizens demand that the government invest more to compensate for deficits. The popularity of healthcare could also be due to the simple fact that the size of the potential constituency for healthcare (everyone gets ill at some point) is larger than that for education (Jensen, 2014). But education continues to receive strong support in countries with a significant degree of underinvestment, such as Germany and Italy.

\section{Public opinion on the distribution of spending across different education sectors}

In addition to asking respondents about their opinion on education spending relative to other social 


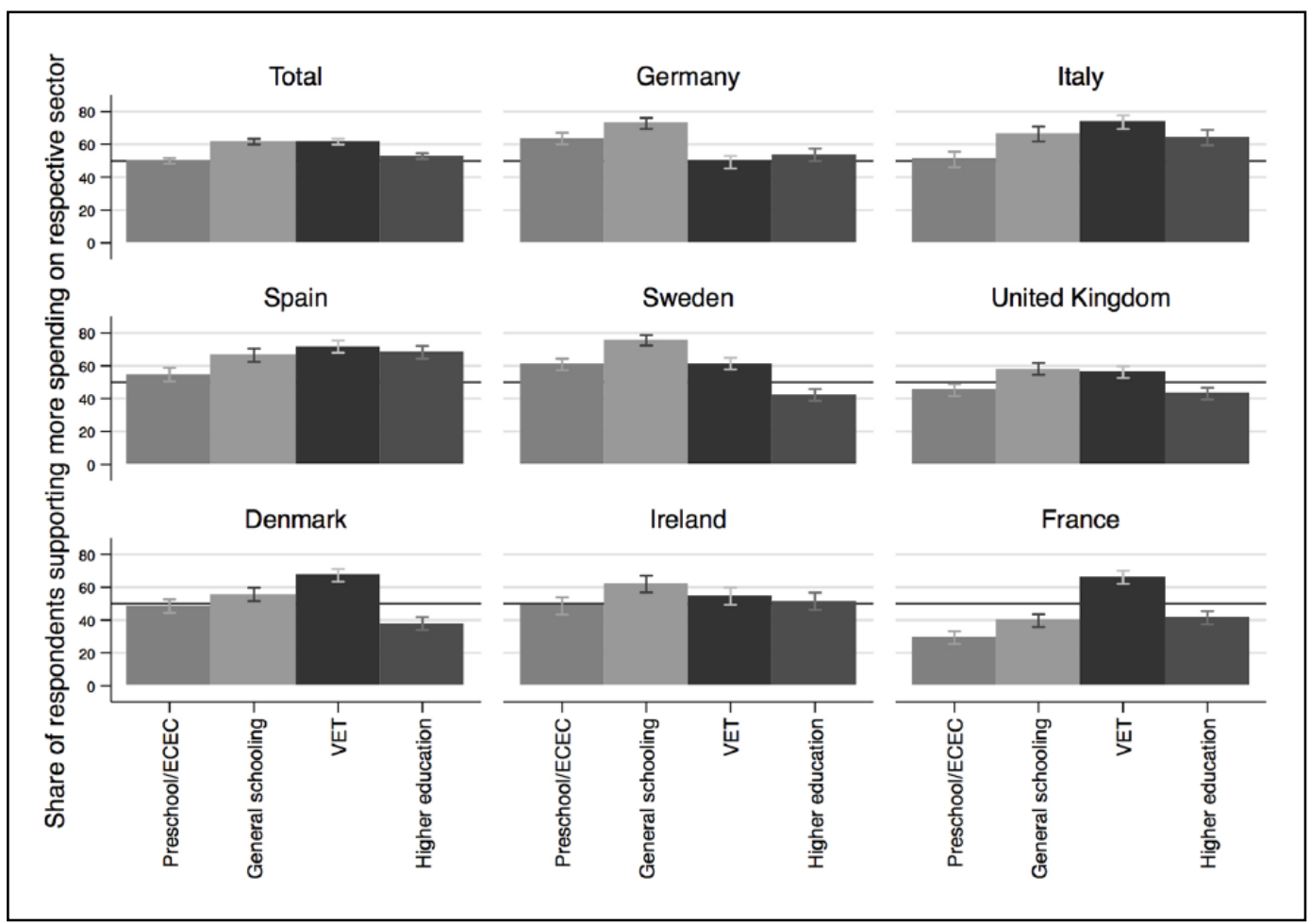

Figure 3. Respondents' preferences for spending on different sectors of the education system across countries.

policies, our survey also contains questions to gauge public attitudes on the distribution of investments across different educational sectors. So far, no international comparative survey has provided this kind of information (but see Busemeyer et al., 2011 for the case of Switzerland and Wößmann et al., 2014 for Germany). We confronted respondents with two questions:

Let's talk about the distribution of public spending in the education sector. Please tell me whether you would like to see more or less government spending in each of the following areas. Keep in mind that 'more' or 'much more' might require a tax increase.

Respondents were offered four answer categories: 'Pre-school and early childhood education', ${ }^{6}$ 'general school education', 'vocational education and training' and 'universities and other higher education'. Of course, we could have differentiated further between even more fine-grained categories (primary as opposed to secondary education, preschool vs. early childhood education and care, and so on), but we believe that these four categories cover the major areas well while keeping the question framing as simple as possible and comparable across countries (the more complex the questions, the more likely it is that less-informed citizens will refuse to answer or will check boxes at random, as is well known in survey research). For each of the four education sectors, respondents were again asked whether they would like to 'spend much more', 'spend more', 'spend the same as now', 'spend less', 'spend much less' or whether they 'don't know'.

A first interesting finding is that there is a considerable degree of variation in support for spending increases across the educational sectors (see the first panel in the upper left corner of Figure 3): if we aggregate across the different countries, support is highest for spending on general school education and on VET. For each of these two sectors, $62 \%$ of the 
respondents are in favour of spending increases. In contrast, support is significantly lower in the case of higher education and early childhood education. ${ }^{7}$ This is a notable finding, because it is usually the latter two that are emphasized in public debates about the expansion of education: as mentioned in the introduction, EU policies specifically aim to increase enrolment in tertiary education, but this apparently does not reflect the priorities of the European public, since spending increases on higher education are supported by only slightly more than half of the respondents (53\%). Equally surprisingly, additional spending on early childhood education is not as popular as could be expected, even though it is a central component of the social-investment model of the welfare state (Bonoli, 2013; Esping-Andersen, 2002; Hemerijck, 2013). The reason why spending on general and vocational education is so popular might be that it is relevant for a larger share of the population (general education) or that people value the connection between education and the labour market (vocational education).

Furthermore, the average levels of support for this question are considerably lower than for the general question about education spending discussed above. As we have already stated, increased spending on education is supported by nearly 80 percent of respondents across the whole sample. In contrast, the share of supporters for more spending, averaged over the four sectors, is only $57 \%$. Respondents are more likely to express their support when asked about education spending on a general, rather abstract level than when they are reminded of the specific educational sectors to which the spending should go. This indicates that respondents have very different parts of the education system in mind when they are asked about 'education spending in general' (in surveys such as the ISSP), making it difficult to interpret these more general questions substantively. In Tables A4-A7 in the online appendix, we analyse this relationship further by cross-tabulating respondents' answers to the more general question on education spending against their preferences towards spending on the specific education sectors. In brief, this exercise seems to confirm the hunch that respondents to the unconstrained question have general schooling and vocational education in mind rather than early childhood and higher education.
As before, there are some notable differences across countries (see Figure 3), although the general pattern from the pooled sample holds across most of the cases. ${ }^{8}$ The comparison between VET and higher education, in particular, is revealing, as these present two alternative educational streams after compulsory secondary education. In all countries (except Germany), there is more public support for increased spending on VET than for higher education. Other than in Germany, the support for increased spending on VET is lowest in the liberal countries, but even in the United Kingdom and Ireland, the average value of the spending support for VET is higher than the value for early childhood education and higher education. Support for spending increases in VET is highest in the Southern European countries confronted with extremely high levels of youth unemployment. ${ }^{9}$ This pattern confirms the impression that VET is highly regarded for its contribution to smoothing the transition from education to employment, and it is particularly in those countries where educational pathways in VET are weakly developed that citizens demand more public investment. However, the relatively low levels of support for VET in the United Kingdom and Ireland also indicate the latent impact of welfare-state and educationpolicy traditions.

In the case of early childhood education, the patterns of public opinion are harder to make sense of. Demand is highest in Sweden, Germany and Spain (about 60 percent each). Sweden already has a well-established system of early childhood education, whereas the latter two are latecomers, although Germany has expanded the provision of childcare recently (Morgan, 2012). Preferences for more public spending might thus arise from the need for better availability of childcare services, and support may be further strengthened once a public system of service provision has been established and private services are crowded out (Busemeyer and Iversen, 2014; Hedegaard and Larsen, 2014). Support for increased spending on childcare is lowest in the United Kingdom and France. France spends a relatively high share of its GDP on early childhood education, and the United Kingdom has expanded spending in this area significantly in recent years. Since the 1980 s, however, the government spending in France has increasingly 
concentrated on subsidizing family day care rather than expanding spending on public day care centres (Morgan, 2005). As a consequence, a growing proportion of children attend this form of care that is characterized by a less-qualified workforce (Morgan, 2005). In the United Kingdom, the expansion of childcare coverage that was initiated in the late 1990s by the New Labour government depends highly on provision by private providers. The expansion of childcare services was accompanied by increasing needs-testing and conditionality for receiving unemployment benefits (Fleckenstein et al., 2011). Following Thatcher's dismantling of the unemployment insurance system in the 1980s, subsequent governments increased their focus on activation and benefit conditionality and aimed at integrating all working-age benefit claimants, including single parents, into the labour market (Clasen, 2011). Such contextual factors might trigger opposition to further spending increases in these two countries. All in all, the variation of public opinion across countries does not reveal a clear pattern of positive or negative feedback. At this point, we can only speculate which idiosyncratic factors might have influenced public opinion one way or another. Further research - for instance, case studies of concrete reform processes - would be needed to clarify these associations more.

Another remarkable finding is the high level of support in all countries for spending increases on general schooling, although a study on the case of Switzerland reports a similar finding (Busemeyer et al., 2011). A simple potential explanation for this observation is that in comparison to the other educational sectors, general schooling (primary and secondary education) is relevant for a larger group of people. Respondents might also believe that investment in basic education is more important than investment in post-secondary education or early childhood education.

In the next set of questions, we once again forced respondents to name just one educational sector in which to concentrate additional investment (Figure 4):

If the government could increase spending for one part of the education system only, which part should the government choose, in your opinion?
Here, respondents had to choose only one of the four education sectors. Again, we randomized the order of the answer categories offered.

On average, general schooling is the category chosen by most (39\%), followed by VET (30\%). In contrast, higher education (17\%) and preschool and early childhood education (15\%) are mentioned to a much lower degree (see the first panel in the upper left corner of Figure 4). Again, however, there are large differences between countries. ${ }^{10}$ General school education is the most chosen category in most countries (although neither in Denmark nor in France) but the level of support varies greatly. In Denmark and France - and to a lesser degree in Spain, Italy and the United Kingdom - the public deems additional spending on VET to be much more important. In turn, pre-primary education is named the top priority in Germany, the United Kingdom and Ireland compared to the other countries. Finally, higher education is prioritized in Italy and Spain.

In short, while we find the highest average demand for expenditure on general school education and VET, there is a lot of country variations, as the populations in the eight surveyed countries seem to have different demands concerning where and how additional education spending is needed. These mixed results might also be related to conflicting preferences among citizens: on one hand, they might be in favour of investing in those education sectors that are as yet only weakly developed and, as such, show promise in helping to solve societal problems (for example VET in Southern Europe). On the other hand, citizens who are sceptical as to whether governments would be willing and able to implement these demands might therefore express support for additional spending on sectors that are already more institutionally developed (for example higher education in Southern Europe). Trust in government might be an important mediating factor in citizens' preferences for different policies, particularly in constrained scenarios.

\section{Willingness to pay for additional spending on education}

A third (hitherto neglected) dimension of public opinion towards investment in education is individuals' 


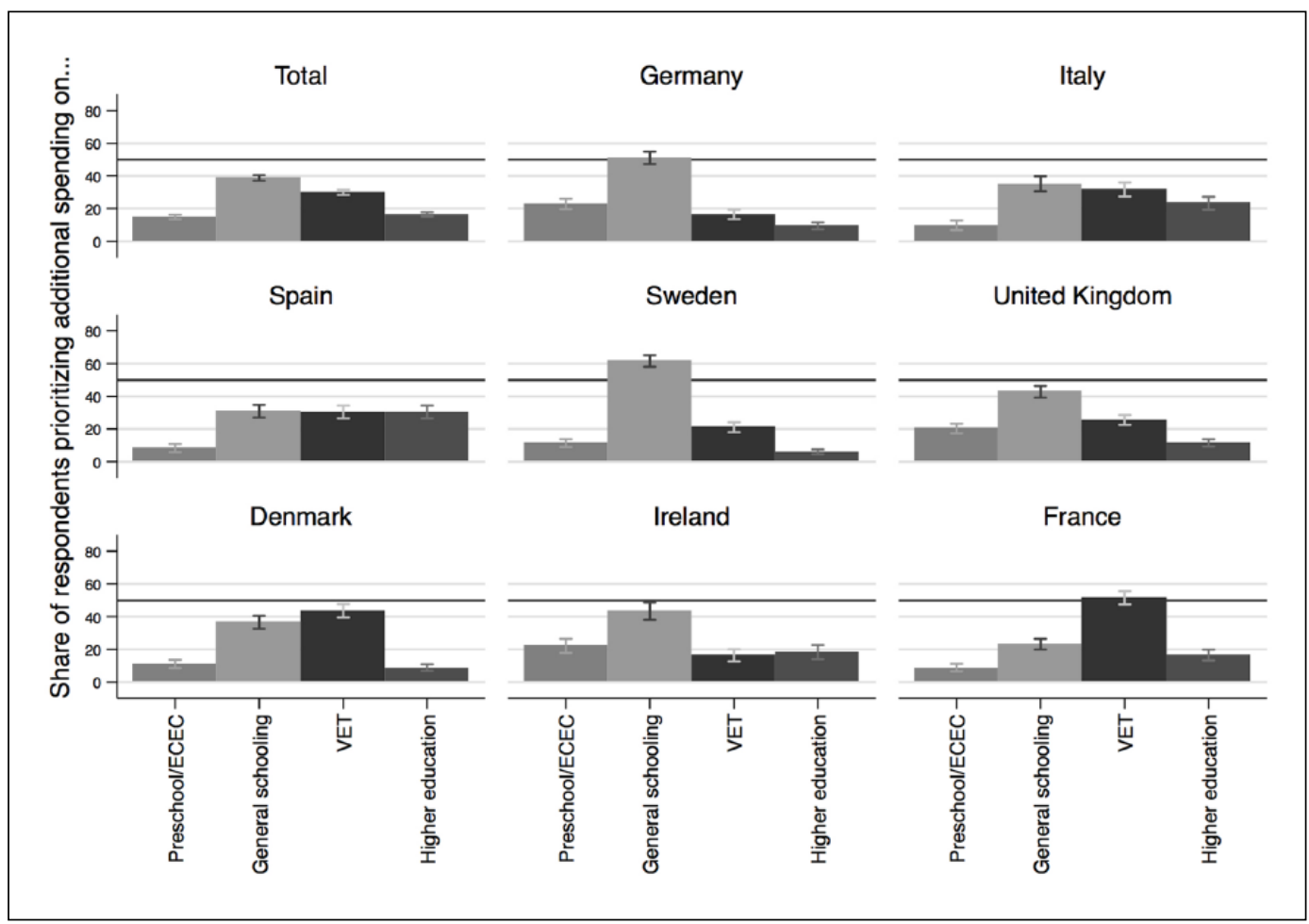

Figure 4. Respondents' preferences for spending on different sectors of the education system, when forced to choose one and only one spending area.

willingness to pay for additional spending, that is, how much extra money citizens are willing to pay in order to finance educational expansion. In the INVEDUC survey, this is measured by a battery of questions in which respondents are confronted with a specific scenario:

Imagine the government proposes a new tax to finance additional investments in the following parts of the education system I will read out to you. Would you support a new tax to finance additional investments in the area of pre-school and early childhood education, general school education, vocational education and training, universities and other higher education?

Respondents were asked about their support for a new tax for each educational sector separately, that is, they could express their willingness to pay for VET but not for higher education, and so on. The findings reveal that public demands for additional education spending (particularly on general school education and on VET) are not just 'cheap talk': averaged across countries, the percentage of respondents willing to accept a new tax is indeed rather high for all sectors (compare the first panel in upper left corner of Figure 5). The distribution of support for additional taxes to finance additional investment in education confirms our previous analyses. Respondents were, on average, more willing to support a new tax to finance investments in general schooling $(57 \%$ of respondents) and VET (54\%) than in higher education and early childhood education. Willingness to accept additional taxes to finance higher education is lowest, with only $38 \%$ of respondents in favour of such a policy proposal, while the respective share of respondents favouring early childhood education is $43 \%$.

Averaged across categories, the results furthermore reveal that the support for additional taxes to 


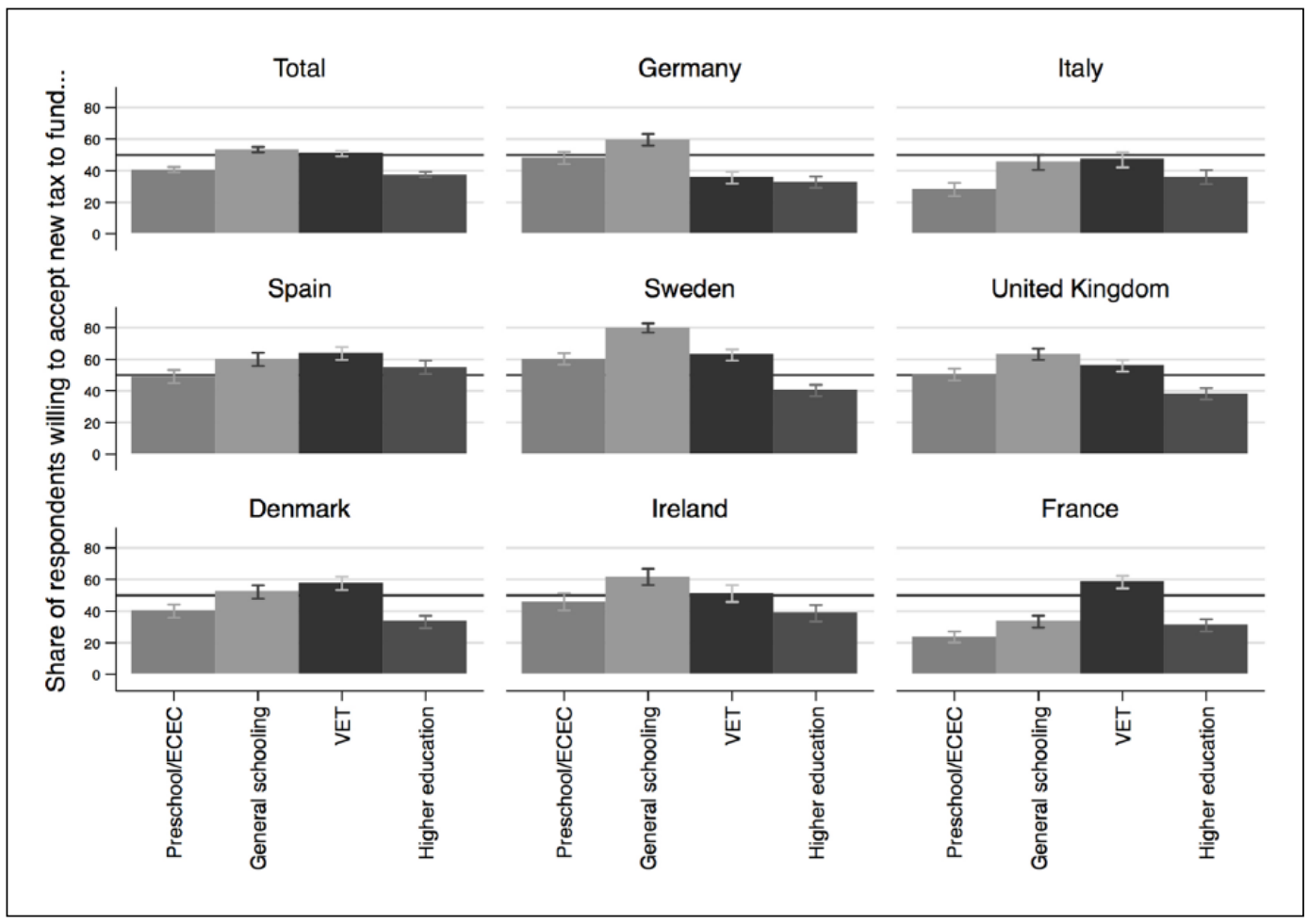

Figure 5. Percentages of respondents willing to pay additional tax for investment in education across countries.

finance education spending is nearly as high as the support for unconditional spending. As a reminder, in the previous question on spending, $57 \%$ of the respondents were in favour of spending increases in at least one area of education spending. The question on taxes shows that $48 \%$ expressed a willingness to accept higher taxes to finance additional spending in at least one area of education spending. Again, $t$-tests confirm that all percentages are significantly different from each other. This is a novel and surprising finding, as previous studies only included 'unconditional' questions and did not ask respondents for their preferences on the 'cost side' of public education spending. It is also interesting to note that whereas about $22 \%$ of the respondents did not support a new tax for any of the four educational categories, $17 \%$ chose just one category, and another $17 \%$ supported new taxes to finance additional investment in all four categories. This indicates a rather complex and nuanced pattern in public opinion on educationrelated tax increases.

When looking at country differences (Figure 5), we find a striking pattern: in some countries, support for additional taxes to finance education spending is nearly as high as support for unconditional spending, while there is a major decrease in support in other country cases. ${ }^{11}$ In Sweden, the difference in the percentage of people expressing strong demands for additional spending and the share of respondents willing to pay for this is smallest: on average, $61 \%$ of Swedish respondents accept additional taxes for at least one area of education spending. Italy, Germany and France are located at the other end of the scale: Italian respondents reveal the strongest discrepancy between spending preferences on one hand and willingness to accept the corresponding taxes on the other. Whereas $64 \%$ demand more spending, only $39 \%$ are willing to pay for this via additional taxes. There is no educational sector in which we find a 
relative majority that would be willing to pay higher taxes. Germany is similar in that respect, with $60 \%$ demanding more spending but only $44 \%$ of respondents willing to pay for this via taxes. France is the country with the lowest absolute percentage of respondents in favour of tax increases. Here, only $37 \%$ of the respondents state their willingness to accept additional taxes for spending increases in at least one area of education spending. However, in France, a majority still favour additional taxes to finance more spending on VET, with $58 \%$ of respondents expressing support. Taken together, our results indicate that citizens are not only demanding more spending but also in some cases they are also willing to pay for this via higher taxes. This implies that despite budget pressures in times of austerity and globalized economies, citizens are still willing to contribute financially to additional expenditures, at least in some countries and in some areas of public spending.

In addition to asking citizens for their general willingness to pay for additional education spending, we asked them about the specific amount (as a share of net income) respondents would be willing to spend. If a respondent replied positively to the previous question, s/he was then asked,

And what percentage of your personal net income would you be willing to pay for these investments in [EDUCATION LEVEL]? Please give a number between 0 and 10 per cent.

This question is particularly important because people might support taxes simply because they assume that they personally are not going to be taxed. Indeed, we find that a number of respondents state that they do not want to pay any additional taxes themselves. This share is rather low, however (6\%). Even if we add those respondents who want to pay less than one percent, the majority of the respondents who support additional taxes are also willing to contribute a significant share of their income themselves. The averages for each of the sectors are quite close to each other, that is, around $4.1 \%$ (with a standard deviation of 2.8).

Figure 6 displays the average share of income citizens are willing to sacrifice in order to increase investment in education. This includes only those respondents who stated their willingness to accept a tax for all of the four areas of education spending in the question mentioned above. The results indicate that in most countries, there are no stark differences across educational sectors with regard to the share of net income that respondents are willing to give up for education. In Germany and Italy, for instance, there are hardly any differences in the amount of money citizens are willing to invest across different educational levels. Accordingly, $t$-tests reveal that the differences between the shares are mostly not significant at conventional levels (detailed results on request).

What is more important, however, is that we again observe significant differences across countries. Citizens in some countries are willing to invest much more than those in other countries: in Italy and Spain, citizens are willing to give up more than four percent of their income to finance additional spending on education, while in Ireland citizens are willing to pay less than two percent on average. These figures should not be interpreted in a literal sense but as a rough proxy measure of the intensity of respondents' willingness to pay, complementing the previous measure from above. An increase in the income tax by four percentage points would be considerable, especially when compared to the fact that education spending represents only a minor component of the public budget (for example in no country does public spending on early childcare exceed two percent of GDP). Nevertheless, the differences across countries and categories provide valuable information for comparisons and can be interpreted as a general indicator of citizens' willingness to back up their demands for more spending with higher taxes.

\section{Discussion and conclusion}

This article is a first step towards increasing our knowledge of the demand side of the politics of education. We present initial findings from an original survey of public opinion on education and related policies, conducted in eight European countries: the INVEDUC survey. The purpose of this article has been empirical and descriptive, that is, to introduce and explore the INVEDUC survey, which has several 


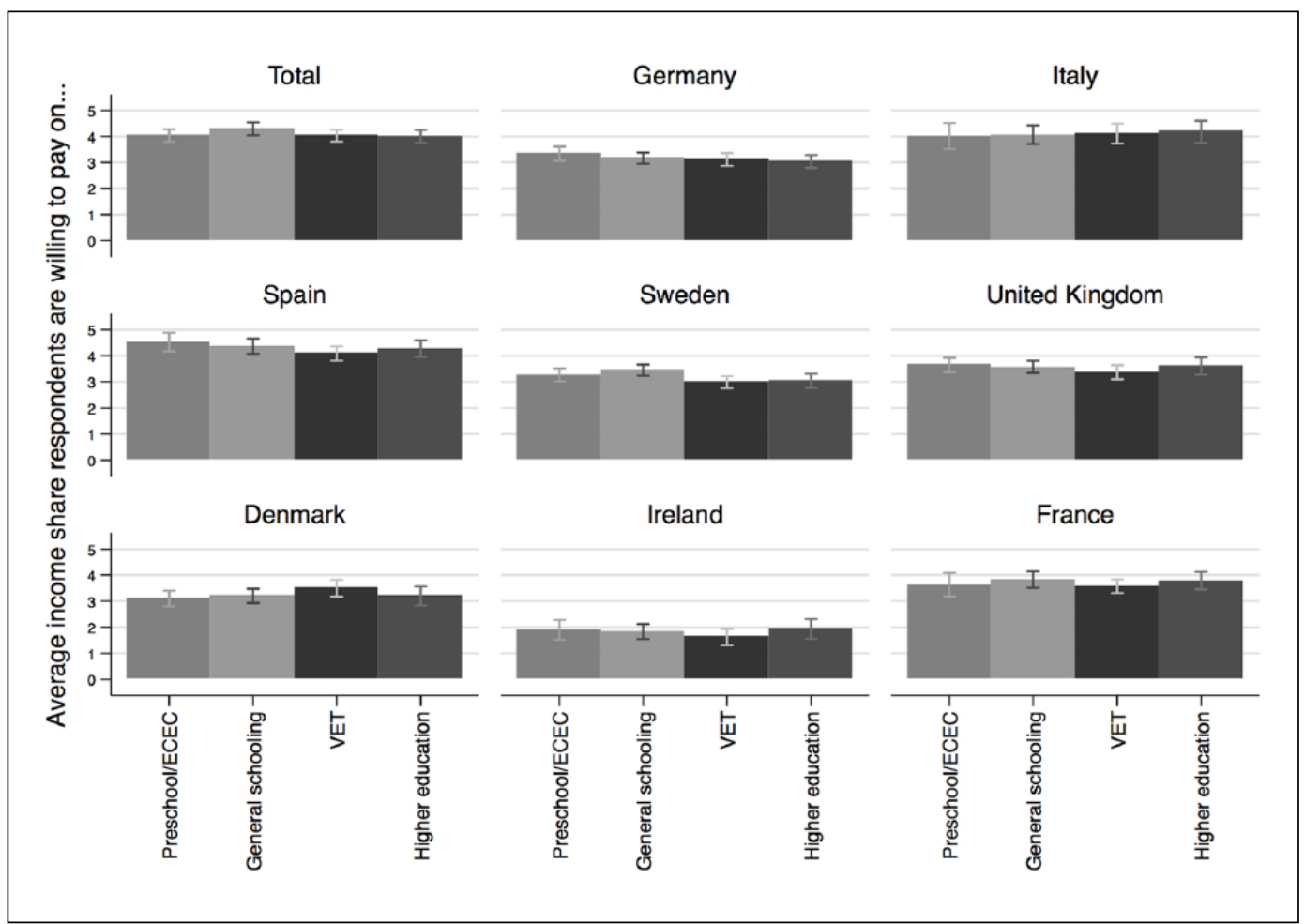

Figure 6. Average share of net income that citizens are willing to pay for additional spending on education.

advantages compared to existing survey data: it forces people to prioritize between spending areas instead of simply asking about their support for spending, presents detailed data on spending preferences across different sectors of the education system and provides a measure of individuals' willingness to pay for additional investment in education through higher taxes. A necessary disadvantage of our survey is that funding constraints only allowed for coverage of eight selected Western European countries. Thus, it remains a task for future research to extend the analysis to a broader set of countries.

Our findings confirm earlier analyses that found a high level of support for education spending (Ansell, 2010; Busemeyer, 2015; Busemeyer et al., 2009, 2011; Garritzmann, 2015, 2016). Our analysis suggests that this support even holds when citizens are forced to choose between increased levels of spending on education and increased levels of other areas of social spending. Only healthcare is equally popular (in some countries). Support for education spending becomes less universal once education is disaggregated into its different sectors ranging from early childcare to higher education. Somewhat surprisingly, the popular demand for spending increases is strongest for general schooling and VET. This support for additional spending on VET is higher than the demand for increased higher education expenditure in the majority of countries, which is at odds with public debates focusing on the expansion of tertiary enrolment. Our data also show that a large percentage of the electorate is willing to pay for additional investment in education (at least in general schooling and VET) via higher taxes. Against a dominant discourse about the unsustainability of public budgets in times of austerity, it appears that citizens are in fact willing to back up their demands for more spending with higher taxes, at least in some countries and for investment in some types of education. We also engaged in some interpretative and 
explorative analysis of cross-country differences in attitudes. For the most part, we found significant indications for the existence of negative feedback effects in the sense of Soroka and Wlezien (2010), that is, citizens supporting policies that are different from the status quo. In other instances, however, the patterns suggested a latent influence of welfare-state traditions: in these cases, citizens' attitudes are largely congruent with the prevailing status quo.

A range of research questions emerge from these findings. First, it is of central interest to evaluate the extent to which public attitudes towards education are relevant for the politics of education. In other words, what do (governing) political parties know about citizens' preferences in policy making, and how much of this do such parties take into account? Are policymakers responsive to public demands? If so, from which group (the general public, partisan constituencies or special-interest groups)? Furthermore, the main purpose of this article was to offer a detailed descriptive overview of public opinion on different types of education policy. We have not yet studied the individual and macro-level determinants of public preferences. One obvious way forward is thus to evaluate which micro-level determinants account for these differences in attitudes, and how different country contexts (institutions) shape the dynamics of preference formation across countries. Drawing on earlier studies in this field (Ansell, 2010; Busemeyer et al., 2009, 2011; Busemeyer and Iversen, 2014; Garritzmann, 2015), we would expect that a combination of material selfinterest and political attitudes (such as ideological orientation, redistribution preferences, and so on) affects people's policy preferences for education (compare also Busemeyer and Garritzmann, 2017). Finally, moving beyond the focus on spending in this article, the INVEDUC survey also provides a mechanism to analyse public preferences for other topics in education policy, such as trade-offs between education and other social policies, as well as preferences for issues such as parental choice, marketization and the decentralization of education. Moreover, studying the relationship between public opinion on public and on private education spending seems highly promising (compare Ansell, 2010; Busemeyer, 2015; Busemeyer and Iversen, 2014; Garritzmann, 2015, 2016), because scholarly knowledge on the public-private division of labour in the financing and provision of welfare-state services is still limited.

\section{Funding}

The author(s) disclosed receipt of the following financial support for the research, authorship, and/or publication of this article: Research for this article is supported with funding from the European Research Council (ERC) with a Starting Grant for the project 'Investing in Education in Europe: Attitudes, Politics and Policies' (INVEDUC), Grant No. 311769.

\section{Notes}

1. http://ec.europa.eu/education/policy/strategic-frame work/index_en.htm

2. Unfortunately, resource constraints did not permit the inclusion of Eastern European and non-European countries. It would obviously have been preferable to have more than two cases per regime type, but given the funding constraints, we wanted to have at least two for each regime in order to avoid the potential idiosyncratic biases of selecting only one case for each.

3. Above and beyond the evidence presented in this article, the survey also contains further questions related to trade-offs in social policy preferences, support for marketization, decentralization, choice reforms, childcare policies, tuition fees and so on. Given space limitations, this survey material will be analysed in subsequent work.

4. In the survey methodological literature, there is a broader discussion on the definition and comparability of response rates. Our response rates are defined as ' 100 - unknown eligibility (for example line busy, no answer) - refusals or break-offs - non-contact (respondent not available)'. As can be seen in the background report (Gensicke et al., 2014: 19, Table 6) the 'refusal' rate is actually not very high, that is, between 30 percent and 40 percent.

5. Because of space limitations, we focus on the major descriptive findings here. Nonetheless, interested readers can find additional information on this relationship in several cross-tabulations in the online appendix (Tables A8-A10.).

6. To avoid ambiguity, the following definition was given to respondents: 'Early childhood education refers to the early childhood educational development for children between 0 and 2 years and pre-school education from the age of 3 to the start of primary education'. 
7. T-tests show that the differences between the percentages for preschool and higher education are not significant, nor are the differences between general schooling and VET. The other differences, however, are statistically significant at the 0.05 level.

8. Again, all of these differences are statistically significant at a 95\% level; the few exceptions are pre-primary and higher education in the United Kingdom; general schooling and VET in the United Kingdom and Ireland; general schooling and higher education in Italy, Spain and France; and VET and higher education in Spain.

9. See cross-tabulations in Tables A9 and A10 in the online appendix.

10. Similar to above, all of these are significant with a few exceptions: pre-primary and higher education in Denmark; general schooling and VET in Italy, Spain and Denmark; general schooling and higher education in Spain (but significant at a 6\% level); and VET and higher education in Spain.

11. All of these shares are significantly different, with the exception of general schooling and VET in Italy and Spain (significant in both on a $15 \%$ level) and general schooling and higher education in Spain and France (significant in both on $15 \%$ level).

\section{References}

Andreß, H.-J. and Heien, T. (2001) 'Four Worlds of Welfare State Attitudes? A Comparison of Germany, Norway, and the United States', European Sociological Review 17(4): 337-56.

Ansell, B.W. (2010) From the Ballot to the Blackboard: The Redistributive Political Economy of Education. New York: Cambridge University Press.

Bean, C. and Papadakis, E. (1998) 'A Comparison of Mass Attitudes towards the Welfare State in Different Institutional Regimes, 1985-1990', International Journal of Public Opinion Research 10(3): 211-36.

Blekesaune, M. and Quadagno, J. (2003) 'Public Attitudes toward Welfare State Policies: A Comparative Analysis of 24 Countries', European Sociological Review 19(5): 415-27.

Bonoli, G. (1997) 'Classifying Welfare States: A TwoDimension Approach', Journal of Social Policy 26(3): 351-72.

Bonoli, G. (2013) The Origins of Active Social Policy: Labour Market and Childcare Policies in a Comparative Perspective. Oxford; New York: Oxford University Press.

Breen, R., Luijkx, R., Müller, W. and Pollak, R. (2009) 'Nonpersistent Inequality in Educational Attainment: Evidence from Eight European Countries', American Journal of Sociology 114(5): 1475-521.
Breunig, C. and Busemeyer, M.R. (2012) 'Fiscal Austerity and the Trade-off between Public Investment and Social Spending', Journal of European Public Policy 19(6): 921-38.

Brooks, C. and Manza, J. (2006) 'Why Do Welfare States Persist?', The Journal of Politics 68(4): 816-27.

Brooks, C. and Manza, J. (2007) Why Welfare States Persist: The Importance of Public Opinion in Democracies. Chicago, IL: University of Chicago.

Busemeyer, M.R. (2009) 'From Myth to Reality: Globalization and Public Spending in OECD Countries Revisited', European Journal of Political Research 48(4): 455-82.

Busemeyer, M.R. (2012) 'Inequality and the Political Economy of Education: An Analysis of Individual Preferences in OECD Countries', Journal of European Social Policy 22(3): 219-40.

Busemeyer, M.R. (2015) Skills and Inequality: The Political Economy of Education and Training Reforms in Western Welfare States. Cambridge; New York: Cambridge University Press.

Busemeyer, M.R. and Garritzmann, J.L. (2017) 'Public Opinion on Policy and Budgetary Trade-offs in European Welfare States: Evidence from a New Comparative Survey', Journal of European Public Policy, forthcoming.

Busemeyer, M.R. and Iversen, T. (2014) 'The Politics of Opting Out: Explaining Educational Financing and Popular Support for Public Spending', SocioEconomic Review 12(2): 299-328.

Busemeyer, M.R. and Trampusch, C. (2011) 'Review Article: Comparative Political Science and the Study of Education', British Journal of Political Science 41(2): 413-43.

Busemeyer, M.R., Cattaneo, M.A. and Wolter, S.C. (2011) 'Individual Preferences for Vocational vs Academic Education: Microlevel Evidence for the Case of Switzerland', Journal of European Social Policy 21(3): 253-73.

Busemeyer, M.R., Franzmann, S. and Garritzmann, J.L. (2013) 'Who Owns Education? Cleavage Structures in the Partisan Composition over Educational Expansion', West European Politics 36(3): 521-46.

Busemeyer, M.R., Goerres, A. and Weschle, S. (2009) 'Attitudes towards Redistributive Spending in an Era of Demographic Ageing: The Rival Pressures from Age and Income in 14 OECD Countries', Journal of European Social Policy 19(3): 195-212.

Busemeyer, Marius R. \& Julian L. Garritzmann (2017) Public Opinion on Policy and Budgetary Trade-offs in European Welfare States: Evidence from a New 
Comparative Survey. Journal of European Public Policy 24(6): 871-889.

Button, J.W. (1992) 'A Sign of Generational Conflict: The Impact of Florida's Aging Voters on Local School and Tax Referenda', Social Science Quarterly 73(4): 786-97.

Campbell, A.L. (2012) 'Policy Makes Mass Politics', Annual Review of Political Science 15: 333-51.

Cattaneo, M.A. and Wolter, S.C. (2009) 'Are the Elderly a Threat to Educational Expenditures?', European Journal of Political Economy 25(2): 225-36.

Citrin, J. (1979) 'Do People Want Something for Nothing? Public Opinion on Taxes and Government Spending', National Tax Journal 32(2): 113-29.

Clasen, J. (2011) 'The United Kingdom: towards a single working-age benefit system', in J. Clasen and D. Clegg (eds) Regulating the Risk of Unemployment: National Adaptations to Post-Industrial Labour Markets in Europe, pp. 15-33. Oxford: Oxford University Press.

De La O, A.L. and Rodden, J. (2008) 'Does Religion Distract the Poor? Income and Issue Voting around the World', Comparative Political Studies 41(4-5): 437-76.

Esping-Andersen, G. (1990) The Three Worlds of Welfare Capitalism. Cambridge: Polity Press.

Esping-Andersen, G. (2002) Why We Need a New Welfare State. Oxford: Oxford University Press.

Fernandez, R. and Rogerson, R. (1995) 'On the Political Economy of Education Subsidies', The Review of Economic Studies 62(2): 249-62.

Finseraas, H. (2009) 'Income Inequality and Demand for Redistribution: A Multilevel Analysis of European Public Opinion', Scandinavian Political Studies 32(1): 94-119.

Fleckenstein, T., Saunders, A.M. and Seeleib-Kaiser, M. (2011) 'The Dual Transformation of Social Protection and Human Capital Comparing Britain and Germany', Comparative Political Studies 44(12): 1622-50.

Garritzmann, J.L. (2015) 'Attitudes towards Student Support: How Positive Feedback-Effects Prevent Change in the Four Worlds of Student Finance', Journal of European Social Policy 25(2): 139-58.

Garritzmann, J.L. (2016) The Political Economy of Higher Education Finance: The Politics of Tuition Fees and Subsidies in OECD Countries, 1945-2015. Basingstoke: Palgrave Macmillan.

Gensicke, M., Hartmann, J. and Tschersich, N. (2014) INVEDUC Final Report. Munich: TNS Infratest Sozialforschung, accessible at: https://www.polver.unikonstanz.de/en/busemeyer/research/

Gingrich, J.R. and Ansell, B.W. (2012) 'Preferences in Context: Micro Preferences, Macro Contexts, and the
Demand for Social Policy', Comparative Political Studies 45(12): 1624-54.

Goldin, C. and Katz, L.F. (2008) The Race between Education and Technology. Cambridge: Belknap Press.

Green, J. (2007) 'When Voters and Parties Agree: Valence Issues and Party Competition', Political Studies 55(3): $629-55$

Groves, R.M. (2006) 'Nonresponse Rates and Nonresponse Bias in Household Surveys', Public Opinion Quarterly 70(5): 646-75.

Harkness, J., Villar, A. and Edwards, B. (2010) 'Translation, Adaptation, and Design', in J. Harkness, M. Braun, B. Edwards, P. Timothy, L. Johnson, P. Lyberg, et al. (eds) Survey Methods in Multinational, Multiregional, and Multicultural Contexts, pp. 11740. Hoboken, NJ: John Wiley \& Sons.

Hasenfeld, Y. and Rafferty, J.A. (1989) 'The Determinants of Public Attitudes toward the Welfare State', Social Forces 67(4): 1027-48.

Hedegaard, T.F. and Larsen, C.A. (2014) 'How Proximate and Visible Policies Shape Self-Interest, Satisfaction, and Spending Support: The Case of Public Service Production', in S. Kumlin and I. Stadelmann-Steffen (eds) How Welfare States Shape the Democratic Public: Policy Feedback, Participation, Voting and Attitudes, pp. 269-88. Cheltenham: Edward Elgar.

Hemerijck, A. (2013) Changing Welfare States. Oxford; New York: Oxford University Press.

Huber, E. and Stephens, J.D. (2014) 'Income Inequality and Redistribution in Post-Industrial Democracies: Demographic, Economic and Political Determinants', Socio-Economic Review 12(2): 245-67.

Iversen, T. and Soskice, D. (2001) 'An Asset Theory of Social Policy Preferences', American Political Science Review 95(4): 875-93.

Iversen, T. and Stephens, J.D. (2008) 'Partisan Politics, the Welfare State, and Three Worlds of Human Capital Formation', Comparative Political Studies 41(4-5): 600-37.

Jaeger, M.M. (2006) 'Welfare Regimes and Attitudes towards Redistribution: The Regime Hypothesis Revisited', European Sociological Review 22(2): 157-70.

Jaeger, M.M. (2009) 'United but Divided: Welfare Regimes and the Level and Variance in Public Support for Redistribution', European Sociological Review 25(6): 723-37.

Jahn, D. (2006) ‘Globalization as 'Galton's Problem': The Missing Link in the Analysis of Diffusion Patterns in Welfare State Development', International Organization 60(2): 401-31. 
Jakobi, A.P., Martens, K. and Wolf, K.D. (2010) 'Introduction: A Governance Perspective on Education Policy', in A.P. Jakobi, K. Martens and K.D. Wolf (eds) Education in Political Science: Discovering a Neglected Field, pp. 1-20. London; New York: Routledge.

Jensen, C. (2014) The Right and the Welfare State. Oxford: Oxford University Press.

Krosnick, J.A. (1999) 'Survey Research', Annual Review of Psychology 50(1): 537-67.

Lergetporer, P., Schwerdt, G., Werner, K. and Woessmann, L. (2016) Information and Preferences for Public Spending: Evidence from Representative Survey Experiments. CESifo Working Paper No 5938, June, Munich: CESifo Group Munich.

Link, M.W., Battaglia, M.P., Frankel, M.R., Osborn, L. and Mokdad, A.H. (2007) 'Reaching the US Cell Phone Generation Comparison of Cell Phone Survey Results with an Ongoing Landline Telephone Survey', Public Opinion Quarterly 71(5): 814-39.

Margalit, Y. (2013) 'Explaining Social Policy Preferences: Evidence from the Great Recession', American Political Science Review 107(1): 80-103.

Mettler, S. and Soss, J. (2004) 'The Consequences of Public Policy for Democratic Citizenship: Bridging Policy Studies and Mass Politics', Perspectives on Politics 2(1): 55-73.

Morgan, K.J. (2005) 'The 'Production' of Child Care: How Labor Markets Shape Social Policy and Vice Versa', Social Politics: International Studies in Gender, State \& Society 12(2): 243-63.

Morgan, K.J. (2012) 'Promoting Social Investment through Work-Family Policies: Which Nations do it and Why?', in N. Morel, B. Palier and J. Palme (eds) Towards a Social Investment Welfare State?, pp. 153-80. Bristol: The Policy Press.

OECD (2014) Education at a Glance 2014: OECD Indicators. Paris: OECD Publishing.

Pennings, P., Keman, H. and Kleinnijenhuis, J. (2006) Doing Research in Political Science: An Introduction to Comparative Methods and Statistics. Chicago, IL: Sage.

Poterba, J.M. (1998) 'Demographic Change, Intergenerational Linkages, and Public Education', The American Economic Review 88(2): 315-20.

Rehm, P. (2009) 'Risk and Redistribution: An IndividualLevel Analysis', Comparative Political Studies 42(7): 855-81.

Rehm, P. (2012) 'Social Policy by Popular Demand', World Politics 63(2): 271-99.

Rehm, P., Hacker, J.S. and Schlesinger, M. (2012) 'Insecure Alliances: Risk, Inequality, and Support for the Welfare State', American Political Science Review 106(2): 386-406.

Scheve, K. and Stasavage, D. (2006) 'Religion and Preferences for Social Insurance', Quarterly Journal of Political Science 1(3): 255-86.

Shavit, Y. and Blossfeld, H.-P. (1993) Persistent Inequality: Changing Educational Attainment in Thirteen Countries. Boulder, CO: Westview Press.

Soroka, S.N. and Wlezien, C. (2010) Degrees of Democracy: Politics, Public Opinion, and Policy. Cambridge: Cambridge University Press.

Steeh, C. (1981) 'Trends in Nonresponse Rates', Public Opinion Quarterly 45(1): 40-57.

Stoop, I., Billiet, J., Koch, A. and Fitzgerald, R. (2010) Improving Survey Response: Lessons Learned from the European Social Survey. Chichester: Wiley.

Streeck, W. and Mertens, D. (2011) Fiscal Austerity and Public Investment: Is the Possible the Enemy of the Necessary? MPIfG Discussion Paper No 11/12, Cologne: Max Planck Institute for the Study of Societies.

Svallfors, S. (1997) 'Worlds of Welfare and Attitudes to Redistribution: A Comparison of Eight Western Nations', European Sociological Review 13(3): 283-304.

Svallfors, S. (2004) 'Class, Attitudes and the Welfare State: Sweden in Comparative Perspective', Social Policy and Administration 38(2): 119-38.

Svallfors, S. (2010) 'Policy Feedback, Generational Replacement, and Attitudes to State Intervention: Eastern and Western Germany, 1990-2006', European Political Science Review 2(1): 119-35.

Svallfors, S. (2012) 'Welfare States and Welfare Attitudes', in S. Svallfors (ed.) Contested Welfare States: Welfare Attitudes in Europe and beyond, pp. 1-24. Stanford, CA: Stanford University Press.

Van Oorschot, W. (2006) 'Making the Difference in Europe: Deservingness Perceptions among Citizens of European Welfare States', Journal of European Social Policy 16(1): 23-42.

Welch, S. (1985) 'The 'More for Less' Paradox: Public Attitudes on Taxing and Spending', Public Opinion Quarterly 49(3): 310-6.

West, A. and Nikolai, R. (2013) 'Welfare Regimes and Education Regimes: Equality of Opportunity and Expenditure in the EU (and US)', Journal of Social Policy 42(3): 469-93.

Wößmann, L., Lergetporer, P., Kugler, F. and Werner, K. (2014) 'Was die Deutschen über die Bildungspolitik denken - Ergebnisse des ersten ifo Bildungsbarometers', Ifo Schnelldienst 67(18): $16-33$. 